UDC 629.3.072.2 (045)

DOI: $10.18372 / 1990-5548.56 .12933$

\author{
${ }^{1}$ N. F. Tupitsin, \\ ${ }^{2}$ M. P. Vasylenko
}

\title{
SAFETY ENHANCEMENT ALGORITHMS OF THE MICRO-UAV PILOTING
}

\author{
${ }^{1,2}$ Aviation Computer-Integrated Complexes Department, National Aviation University, Kyiv, Ukraine \\ E-mails: ${ }^{1}$ nift@mail.ru, ${ }^{2}$ m.p.vasylenko@nau.edu.ua
}

\begin{abstract}
The article is devoted to algorithms development of piloting with enhanced safety for micro$U A V$. The critical situations arising during the flight, typical failure of the electrical equipment of the ground station communication from the unmanned aerial vehicle and the radio equipment of the unmanned aerial vehicle are taked into account. Also, the synthesis of the unmanned aerial vehicle emergency landing algorithm is held. The technical realization of the emergency landing algorithm is realized on the basis of micro-UAV PD-1900. Beside, the safety enhancement algorithm of the micro-uav piloting is developed.
\end{abstract}

Index Terms-Algorithms piloting; micro-UAV PD-1900; typical failures; emergency landing; manual control system.

\section{INTRODUCTION}

The emergence of a critical situation during the flight, and most importantly, wrong response from the pilot side, can lead to an aviation event. This, in turn, generates four problems.

1) The task left unfulfilled.

2) The reason for the incident is unclear. lost.

3) The unmanned aerial vehicle (UAV) itself

4) Damage caused by an accident UAV.

Problems 2 and 3 do not have serious consequences - these are just technical issues. However, issues 1 and 4 are essential because they are a problem for the customer and people or even the environment.

In order to prevent such a large number of problems, it is enough to minimize the pilot's mistakes, prevent the emergence of emergency situations and control the flight at any given time. Therefore, the question arose in improving the safety of piloting.

Thanks to well-built piloting algorithms that take into account the maximum number of negative factors and events that may occur, the piloting process can be brought to a new level. The software emergency response with minimizing an external pilot (EP) intervention in the piloting process, as well as a set of measures to reduce technical failures, improve the current measures to increase the safety of the UAV and significantly reduce the number of aviation events.

The development of a fundamentally new algorithm for emergency landing of UAVs, which can be carried out even if the telemetry signal is specific, can significantly improve the safety of piloting. And the combination of the algorithm and the complex before the flight checks can reduce the likelihood of failure of the technical nature.

\section{PROBLEM STATEMENT}

For each UAV there is a unique bounce list that varies greatly among them, therefore, the following failures are typical of the PD-1900 used in the UAV [1]:

- electrical equipment (due to electric shock or battery discharge);

- radio equipment (high level of interference, closure, loss of signal);

- servo drives control (ailerons, elevator, and ruder);

- damage to external contours;

- faulty control panel;

- invalid route task;

- weather conditions (precipitation, wind more than $10 \mathrm{~m} / \mathrm{s}$ ).

Due to the presence of a sufficient number of typical failures on the micro-UAV, the task is to reduce critical situations during the flight, minimize the impact of the pilot's mistake on the management process and on the refusals, as well as prolong the life of the UAV.

\section{PROBLEM SOLUTION}

Most aviation events involving the UAV occur due to the fault of an external pilot, but there are other factors. Flihgt safety is influenced by four main factors:

1) human (EP error);

2) equipment (technical failure of the UAV);

3) weather conditions;

4) random external factor.

Since it is not possible to track and predict an accidental external factor during a flight, but three other factors can be prevented.

The human factor can be the lack of flight practice, the physical condition of the EP, knowledge 
and skills to respond to critical situations, launch and landing errors, and so on.

The equipment factor includes the lack of completeness of components and parts of the UAV, the performance of individual parts of the UAV and the ground station, lack of technical inspection and planned repairs, and so on.

Weather conditions play an important role in the safety of piloting, and it is precisely because of noncompliance with the operating standards of the UAV, abrupt changes, complications of meteorological conditions, aviation events occur.

According to a study conducted by the Aviation Week \& Space Technology [2], about $76 \%$ of aviation events in the UAV occur due to mistakes made during the flight preparation process, and they have led to critical airborne effects. Therefore, due to the factors of danger, it is expedient to give considerable attention to the political tests.

The external pilot follows the following criteria:

1) Ability to launch control system and their warming during the pre-flight training and identify their malfunctions that arise during this period.

2) Perform UAV take off depending on the conditions of the base, the atmosphere, the power of the aircraft and other factors.

3) The EP the UAV on the route or in the aerodrome zone in accordance with the set task.

4) To carry out UAV landing depending on the conditions of the base, the atmosphere and characteristics of the concrete UAV sample.

5) Adequately respond to abnormal situations that arise during take-off, flight in or on the route, and during landing.

6) To be able to carry out an emergency landing with minimal losses of the MF and with minimal danger to the environment, buildings and people.

7) Build a flight task, set route parameters depending on weather conditions and takeoff.

8) Select the correct take-off and landing point if the flight is outside the aerodrome.

9) The physical condition of the EP must meet the standards.

The complete equipment of the UAV PD-1900 consists of a ground station and UAV, which are allocated the following criteria:

1) Availability of all components and nodes.

2) All mechanisms must be capable of operation and secured.

3) The software should be the latest version, both in the ground station and in the UAV.

4) The batteries of the aircraft, remote control, and ground station must be fully charged.

5) Presence of repair kit with all necessary spare parts and consumables for flight.
Weather conditions play a key role in aviation, which is why it all depends on its success or vice versa failure of the flight. Like all other criteria, special attention is given to meteorological conditions, since it is necessary to take into account not only its fluid state at the take-off point, but also to know the weather conditions for the entire flight time and in all areas of UAV flight. Taking into account the design features, the technical characteristics of the UAV PD-1900 weather conditions must meet the following criteria:

1) The wind force shall not exceed $10 \mathrm{~m} / \mathrm{s}$.

2) Visibility should be at least $300 \mathrm{~m}$.

3) No precipitation, except dry snow.

Separately, the take-off and landing site of the UAV should be distinguished if the flight takes place outside the air force. According to [2], approximately $71 \%$ of aviation events occur precisely during takeoff or landing of UAVs. That is, the right choice for take-off and landing gives the outside EP more opportunities for precise take-off and landing, time to make a decision in the event of a critical situation, the possibility of an additional boarding range, maintenance of the serviceability and integrity of the UAV, better opportunities. Taking into account the technical characteristics and design features of the UAV PD-1900 to the take-off and landing site, the following conditions are taken into account:

1) The surface within a radius of $30 \mathrm{~m}$ should be even and clean from foreign objects and plants (trees, shrubs, power lines, etc.).

2) The take-off and landing site must be located within the radius of the ground station, preferably away from the objects that may affect the signal.

3 ) If the flight will be conducted near airports, security facilities, etc., departure should be agreed with the management.

Consequently, compliance with these prior to flight checks is an integral part of the safety improvement algorithm. The consistency and correctness of these actions is the basis for a successful flight.

\section{EMERGENCY LANDING ALGORITHM}

An external pilot is responsible for the safety of the flight, people or property that may suffer in front of the customer: for the failure of the task, the damage caused by the aircraft event, and for the equipment that was damaged in the accident. The EP must have the knowledge and skills that will help them to make the right decision quickly and correctly in a critical situation.

But the exceptions are the events from which the EP's actions will not flush the result. In the class of 
the micro-UAV, such events can include flights at low altitudes (up to $50 \mathrm{~m}$ ), the event is discarded for 1-3 s, the disappearance of the telemetry signal at the ground station during flights outside the UAV's view, because the signal delay lasts $1-8 \mathrm{~s}$, which for making decision is critical.

The usual procedure for improving the safety of piloting the micro-class UAVs operating on Ardu Pilot controllers is to turn on the "return home" mode when emergencies occur. This mode allows you to return the UAV to the take-off point at the height that it is pre-assigned. From my own experience, I can say that this mode allows you to solve an emergency situation that concerns only the disappearance of the telemetry signal. This method is not effective in terms of weather conditions, low battery discharge; long distance from the take-off point, signal interception, and situations where decisionmaking is a short time.

Considering specific typical situations, one can distinguish such algorithms for decision-making.

When the telemetry signal is lost (Fig. 1):

1.a At an instantaneous loss of the signal -1 it is necessary to send antenna on the UAV -2 . When the signal appears, transfer the flight to automatic mode or landing -6 .

2.b If it does not lead to a signal or the loss of a signal more than 8 seconds, you will need to turn on the "Return home" mode on the remote control or the base station -3 . When the signal appears, transfer the flight to automatic mode or landing -7 .

3.c If this action does not lead to the appearance of a telemetry signal, it is necessary to go to the UAV meeting - 4, before the signal or visual control from the UAV. When the signal appears, transfer the flight to automatic mode or landing -8 .

4.d If these measures did not lead to the appearance of a telemetry signal, then we can assume that there was an aviation event -5 .

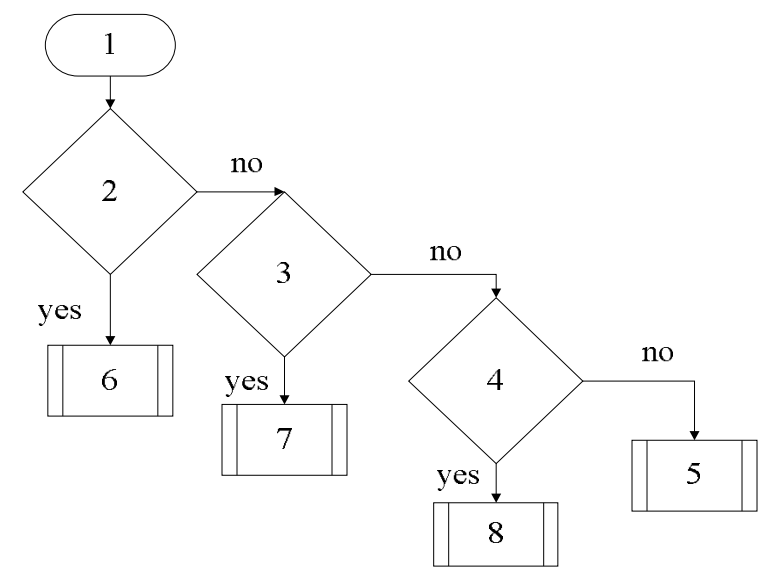

Fig. 1. Flight algorithm with the disappearance of the telemetry signal
In the case of a sharp disappearance of the telemetry signal, it is necessary:

1.e You need to turn on the "Return home" mode on the remote control. Make landing immediately, at the onset of visual control.

2.f If this action did not lead to the elimination of the critical situation, then it is necessary to go to the UAV and at appearance visual control with it to make landing.

3.g If these measures did not lead to the elimination of the critical situation, then we can assume that there was an aviation event.

By analogy, in the event of a technical malfunction during the flight, which allows piloting of the $\mathrm{UAV}$, it is necessary:

1.h You need to turn on the "Return home" mode on the remote control. To make landing immediately, at the onset of visual control.

$2 . i$ If this action did not lead to the elimination of the critical situation, it is necessary to transfer the UAV using the control switches to the "Stabilized flight" mode, and to try to land.

3.j If the "Stabilized Flight" mode does not result in the control of the UAV, then it is necessary to transfer it with the help of the toggle switches or the control ground station into "Manual Flight" mode and try to land.

$4 . k$ If the "Manual Flight" mode does not result in the control of the UAV, then it can be assumed that there was an aviation event.

So, when aggregation of telemetry faults, deterioration of weather conditions or technical malfunctions it is necessary:

1) You need to execute actions 1.e, 2.i, and later 3.j.

2) In a result we can receive $4 . k$.

Considering such algorithms for responding to critical situations when piloting a micro UAV with an ArduPilot autopilot, the need appeared to create a new flight security algorithm that would more likely to reject such events.

The algorithm of critical landing are actions aimed at increasing the probability of a successful landing, increasing the level of piloting safety, at which, at the moment of a critical situation, the UAV, in the place where the incident occurred, falls to a safe altitude and automatically makes landing irrespective of the direction of the wind. The reduction takes place in a spiral, which in turn allows the EP to take a subsequent decision or to land a landing independently of the telemetry signal and weather conditions during the time of reduction.

This algorithm begins with the autopilot setting mode and synchronization the channels of the console and the ground station. In the autopilot set-up, 
the "Loiter (Hovering)" function is selected and the permissible lower altitude is shown, based on the trajectory location. This is done so that the UAV at falling down does not collide with foreign objects on its way.

Such a permissible height is the highest point in the flight zone with an additional stock of 10-15 m, depending on the accuracy and error of the UAV altimeter. After lowering the UAV to the given point, whirling around it, the radius of decrease and turning is selected based on the technical characteristics of the UAV so as to prevent overload during the downward and circling.

This mode allows you to solve typical critical situations, when it is not possible to control the UAV flight, to quickly respond and to land the UAV without the participation of the EP. In addition, the EP at any moment can intercept the control of the UAV into one's hands. After this stage, the EP can independently decide on the further continuation of the flight. If no decision can be taken, based on the criticality of the situation or the state of the UAV, the next step of the emergency landing is performed.

With the help of autopilot settings, the mode on the control panel or on the ground station "Stabilization Flight" is switched on, at which the altitude is reduced, not exceeding the permissible an angle of attack and given speed of the UAV. The approach angle and approach speed are chosen solely from the technical characteristics of the UAV used in such a way that there is no overload greater 1.The algorithm of critical landing is presented in Fig. 2.

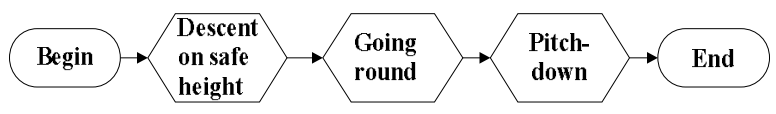

Fig. 2. Emergency landing algorithm

Since the emergency landing consists of a process of descent and stand-alone landing, each of these components can be used separately as a tool to overcome critical situations.

When using this sequence of actions (see Fig. 2), it is necessary to activate the circling mode in advance of the critical height, not less than $30 \mathrm{~m}$.

Another case of using a possible application is only the dive (pitch-down) function until the planting itself. The reasonability of this measure is possible in the event of a critical situation, over large settlements, when the battery is discharged above the terrain where it is not possible to land or the surface is not intended for landing.

With regard to UAV PD-1900, then the approach angle for it should not exceed 15 degrees, and the approach speed is up to $8 \mathrm{~m} / \mathrm{s}$. These figures are based on the technical characteristics of the UAV and are experimentally confirmed.

This algorithm of emergency landing can be used on different designs of UAV aircraft type, working on autopilot ArduPilot or derivatives from it. For using this algorithm on other types of autopilots, it is necessary only the presence of the regimes "Stabilization Flight" and "Loiter".

The landing algorithm is consisted of main three parts: descent to safe height, hovering and landing. The process of reducing and freezing is configured as follows. First, you must adjust the height reduction mode. The tuning of autopilot control is executed in the Mission Planner program.

It is necessary to set set the third additional flight control channel "Loiter" in the Con fig / Tunning tab, under Flight Modes (Fig. 3).

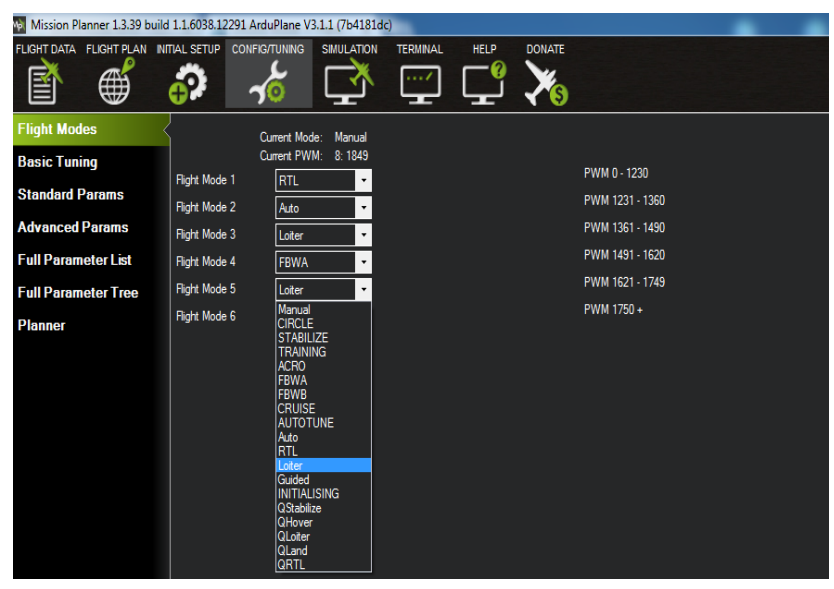

Fig. 3. Setting the "Loiter" mode

This mode allows you to hold the position make circles about the point where it was applied. With the GPS receiver the point, in which the "Loiter" mode was used, is held in the controller's memory. In this mode, there is also complete stabilization of the flight. Permissible wind, at which it is possible to hold this point without displacement is equal to $10 \mathrm{~m} / \mathrm{s}$.

The radius of rotation is given as follows. You need to set "Waipoint Loiter Radius" parameter (WP_Loiter_Rad) in the Configuration / Tunning tab in the Standard Params section. As folows from the experimental research, the optimum radius of rotation is approximately $80 \mathrm{~m}$. Next step is to set the height of the hovering. It is necessary to set the value of Loiter_U to $30 \mathrm{~m}$ in the Flight Data tab, the "Actions" section. This height is chosen depending on where the flights are conducted now. The height is chosen so that on the way of its circles the UAV did not come across an obstacle. In this case, the height of 30 meters totally corresponds to this.

Now, after turning on the "Loiter" mode, the UAV from the given altitude will desent to the 
height of the hover. Experimentally it was determined that the reduction speed is $0.7 \mathrm{~m} / \mathrm{s}$ for UAV PD-1900. This indicator may vary depending on the wind speed.

The process of autonomous landing is configured as follows. It is necessary in the Flight Modes, the section "Config / Tunning", on the fifth additional channel to set the "Cruises" mode. This flight mode allows you to perform a stabilization flight, but with pre-defined settings for the flight speed and pitch angle.

Next you need to adjust the speed and pitch angle. In the Config / Tuning tab, the Standard Params section,it's necessary adjust the Mount title / pitch, when retracted position (MNT retract $\mathrm{Y}$ ) parameter, to set the angle of 10 degrees. Namely, the pitch angle 10-15 degrees is optimal for the UAV PD1900 at landing. In order to ensure the optimal approach speed, you must do the following: adjust the Maximum Airspeed and Minimum airspeed in the Standard Params section, the Config/Tunning tab.

Let's set indicators 7 and 6, respectively. This parameter will allow us to fix the approach speed from 6 to 7 meters per second, which is recommended for the UAV PD-1900. If the speed parameters relative to the ground are lower than the wind speed or $40 \%$ higher, then the Autotune level (Autotune level) adjusts the speed relative to the ground to $5 \mathrm{~m} / \mathrm{s}$.

This function is intended to avoid landing at a very high speed (greater than $10 \mathrm{~m} / \mathrm{s}$ ) or low (less than $5 \mathrm{~m} / \mathrm{s}$ ), when landing downwind, upwind or perpendicular to wind.

\section{Flight SAFETy AlgORITHM OF MicRo-UAVS}

One of main tasks of UAV PD-1900 is to scan the surface. A feature of the scanning process is the flight over the points given in the form of a zigzag, during which aerial photography takes place (Fig. 4).

To get the desired level of photo overlays, the points are set in this way. Scanning is often done for relatively large areas, for example, near 200 hectares. This suggests that the plane has to pass a fairly large route, about $60 \mathrm{~km}$ per flight on one accumulator, which for a UAV of such a class is significant.

In addition, depending on the weather conditions, the battery charge can reach critical levels $-11.2 \mathrm{~V}$, so it can be one of the factors that affect the safety of piloting.

In the Figure 4 is shown neighbourhood of Tashan village, Kyiv region, Pereyaslav-Khmelnitsky district. The survey area is 250 hectares. At moment of work the wind was from northwest, so the route was built perpendicular to the wind and the swivelings of the UAV were served against the wind.

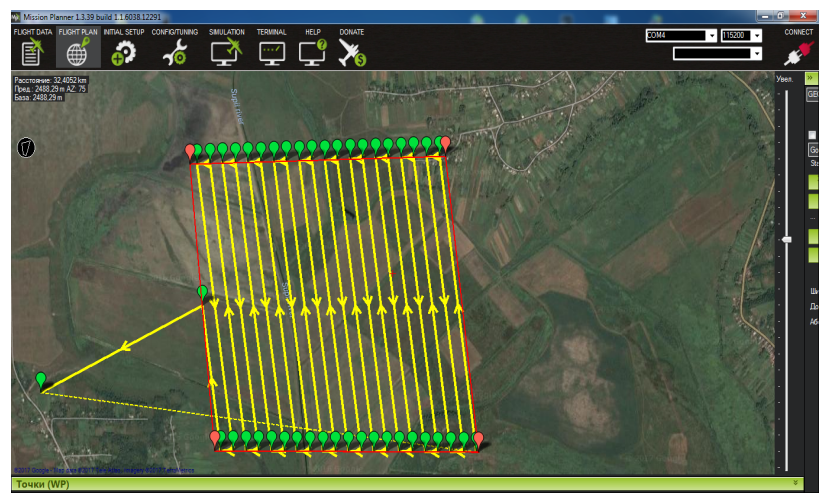

Fig. 4. The PD-1900 UAV Route task for surface scaning

Taking into account such tasks, below is constructed a safety enhancement algorithm of piloting.

First, it is necessary to execute pre-flight checking (Fig. 5). After passing pre-flight checkings, being sure of the weather conditions and the take off place, by constructing the flight task, you can proceed to the next stages: the UAV launching and a flying through the route points.

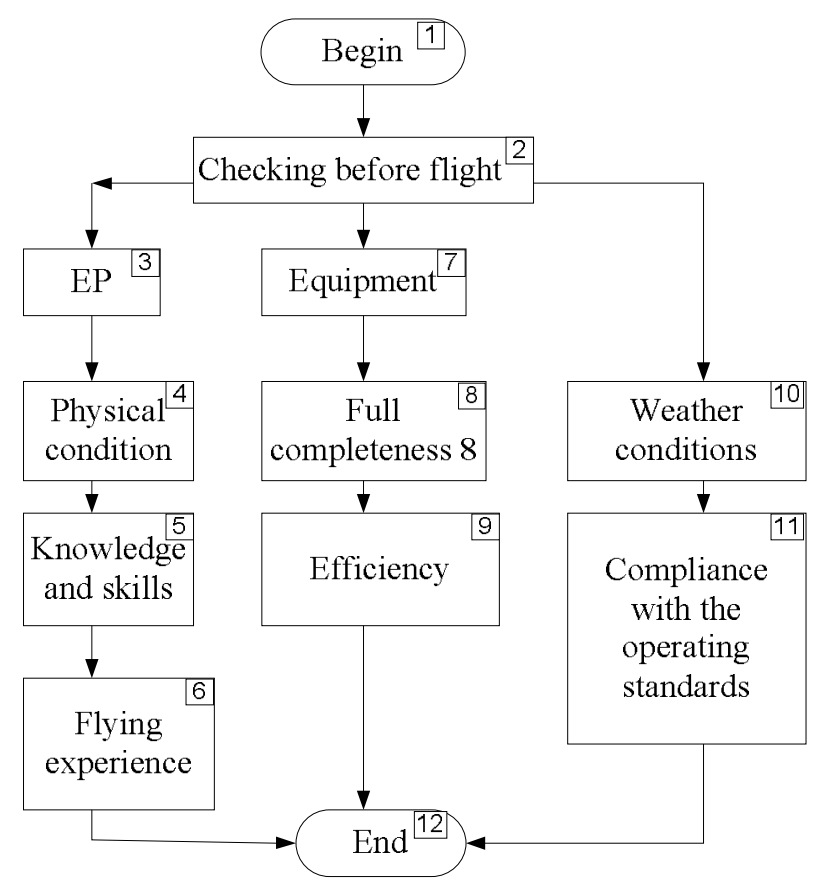

Fig. 5. Pre-flight checking algorithm

This algorithm was designed such a way as to maximally anticipate possible critical situations.

During critical situations in which it is impossible to observe the telemetry of the UAV, at moment, when it is necessary to react quickly to the event, the given algorithm will allow lowering it to a safe altitude and provide landing without the participation of an external pilot (Fig. 6).

Consider each of the blocks of the algorithm.

Block 1 is the start of algorithm work, namely, i.e. completion of the pre-flight checking. 
Block 2 is the launch of the UAV, which is performed from a hand or with help by a catapult. If the startup is in normal mode, then is executed Block 3.

However, during the launch, the following critical situations are possible, such as drawdown of height at launch, the failure of the electronics of the UAV.

Block 5 corresponds to the process of eliminating failures. In this case next actions can be taken by the external pilot:

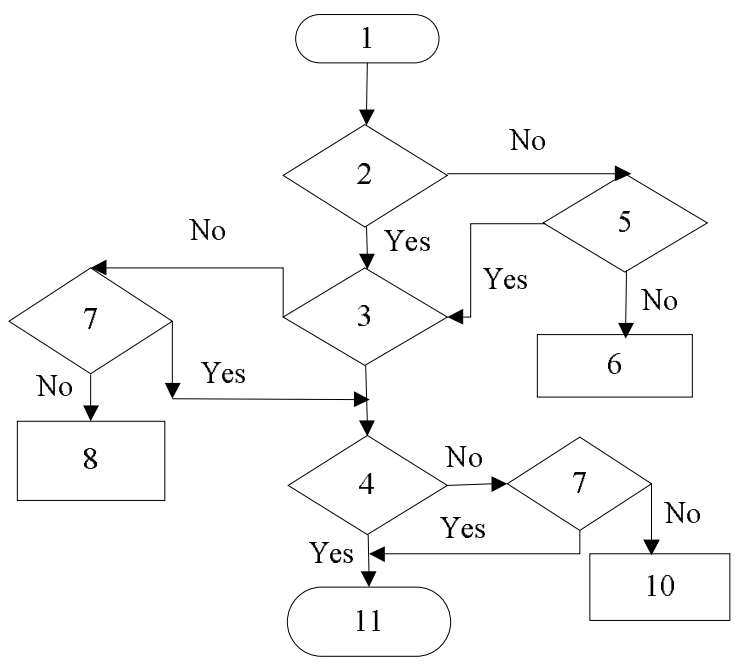

Fig. 6. The PD-1900 safety improvement algorithm

1) Transfer the UAV to manual flight mode with subsequent withdrawal to the working height.

2) Switch off the engine during take-off. Next, the UAV is restarted.

If the problem is not solved, than is executed Block 6.

Block 3 is a performance of regular flight. In our case, it is aerial photo shooting of the village. If it passes normally, then is executed the next phase. During the flight, the following critical situations may occur:

1) the disappearance of the telemetry signal;

2) changes in weather conditions that do not comply with the norms of the UAV operation;

3) the appearance of technical malfunctions in the process of performing the task;

4) set of series negative factors.
Block 7 is a process of troubleshooting. If standard algorithms reaction do not lead to an exit from a critical situation, an emergency landing should be used (Block 8).

Block 4 is the regular UAV landing after completing the flight route. During landing the following critical situations are possible:

1) changes in weather conditions that do not comply with the norms of the UAV operation;

2) the appearance of technical malfunctions in the process of landing;

3) set of negative factors;

4) high speed at landing;

5) rough landing.

To prevent high-speed landing, it is necessary to control the pitch angle so that its value does not below minus 15 degrees. In order to prevent a rough landing, it is necessary to control the approach speed and the chosen point of landing must be equal and without foreign objects, becouse it could cause damage to the equipment. If a critical situation is not eliminated the EP must make a decision on emergency landing (block 10). Block 11 is the end of algorithm work.

\section{CONCLUSION}

In the paper algorithms for responding to critical situations that arise during the flight are constructed.

The technical realization of the emergency landing algorithm is realized on the basis of micro-UAV PD-1900. Beside, the algorithm for improving the safety of the PD-1900 flight piloting has been developed. This algorithm may be useful for other types of micro-UAV.

\section{REFERENCES}

[1] http://zala.aero/zala-421-16e-2/

[2] Heather Baldwin. Human Factors in Unmanned Aircraft Operations/UAV operations pose new MRO challenges//Aviation Week \& Space Technology. Sep 08, 2014.

Received March 01, 2018.

Tupitsin Nikolay. Candidate of Science (Engineering). Associate Professor.

Aviation Computer-Integrated Complexes Department, National Aviation University, Kyiv, Ukraine.

Education: Moscow Phisics-thechnical Institute, Moscow, Russia (1975).

Research area: dynamic of flight, experimental methods of aerodynamic, aviation simulators.

Publications: 92.

E-mail: nift@mail.ru

Vasylenko Mykola. Candidate of Science (Engineering). Associate Professor.

Aviation Computer-Integrated Complexes Department, National Aviation University, Kyiv, Ukraine.

Education: Kyiv National University of Technologies and Design, Kyiv, Ukraine (2012).

Research interests: renewable energy sources, thermal noise based estimation of materials properties. 
Publications: more than 20 papers.

E-mail: m.p.vasylenko@nau.edu.ua

М. Ф. Тупіцин, М. П. Василенко. Алгоритми підвищення безпеки пілотування мікро-БПЛА

Стаття присвячена розробцы алгоритмів пілотування мікро-БПЛА з підвищеним рівнем безпеки. До уваги взято критичні ситуації, що виникають під час польоту, такі як відмови електричного обладнання наземної станції зв'язку з БПЛА та радіообладнання самого БПЛА. Проведено синтез алгоритму автоматичної посадки. Технічна реалізація алгоритму аварійної посадки здійснювалася на базі мікро-БПЛА PD-1900. Окрім цього, алгоритм підвищення безпеки пілотування мікро-БПЛА розроблено.

Ключові слова: алгоритми пілотування; мікро-БПЛА PD-1900; типові відмови; аварійна посадка; система ручного керування.

Тупіцин Микола Федорович. Кандидат технічних наук. Доцент.

Кафедра авіаційних комп’ютерно-інтегрованих комплексів, Національний авіаційний університет, Київ, Україна. Освіта: Московський фізико-технічний інститут, Москва, Росія, (1975).

Напрям наукових досліджень: динаміка польоту, експериментальні методи аеродинаміки.

Кількість публікацій: 92.

E-mail: nift@mail.ru

Василенко Микола Павлович. Кандидат технічних наук.

Кафедра авіаційних комп’ютерно-інтегрованих комплексів, Національний авіаційний університет, Київ, Україна. Освіта: Київський національний університет технологій та дизайну, Київ, Україна (2012).

Напрям наукової діяльності: відновлювальні джерела енергії, оцінка властивостей речовин та матеріалів за власними електромагнітними випромінюваннями.

Кількість публікацій: більше 20 наукових робіт.

E-mail: m.p.vasylenko@nau.edu.ua

Н. Ф. Тупицин, Н.П. Василенко. Алгоритмы повышения безопасности пилотирования микро-БПЛА

Статья посвящена разработке алгоритмов пилотування микро-БПЛА с повышенным уровнем безопасности. Приняты во внимание критические ситуации, которые возникают во время полета, такие как отказы электрооборудования наземной станции связи с БПЛА и радиооборудования самого БПЛА. Проведен синтез алгоритма автоматической посадки. Техническая реализация алгоритма аварийной посадки осуществлялась на базе микроБПЛА PD-1900. Кроме того, разработан алгоритм повышения безопасности пилотирования микро-БПЛА. Ключевые слова: алгоритмы пилотирования; микро-БПЛА PD-1900;типовые отказы; аварийная посадка; система ручного управления.

Тупицин Николай Федорович. Кандидат технических наук. Доцент.

Кафедра авиационных компьютерно-интегрированных комплексов, Национальный авиационный университет, Киев, Украина.

Образование: Московский физико-технический институт, Москва, Россия (1975).

Направление научной деятельности: динамика полета, экспериментальные методы аэродинамики.

Количество публикаций: 92.

E-mail: nift@mail.ru

Василенко Николай Павлович Кандидат технических наук.

Кафедра авиационных компьютерно-интегрированных комплексов, Национальный авиационный университет, Киев, Украина.

Образование: Киевський национальний университет технологий и дизайна, Киев, Украина (2012).

Направления научной деятельности: возобновляемые источники энергии, оценка свойств веществ и материалов по их собственным электромагнитным излучениям.

Количество публикаций: больше 20 научных робот.

E-mail: m.p.vasylenko@nau.edu.ua 